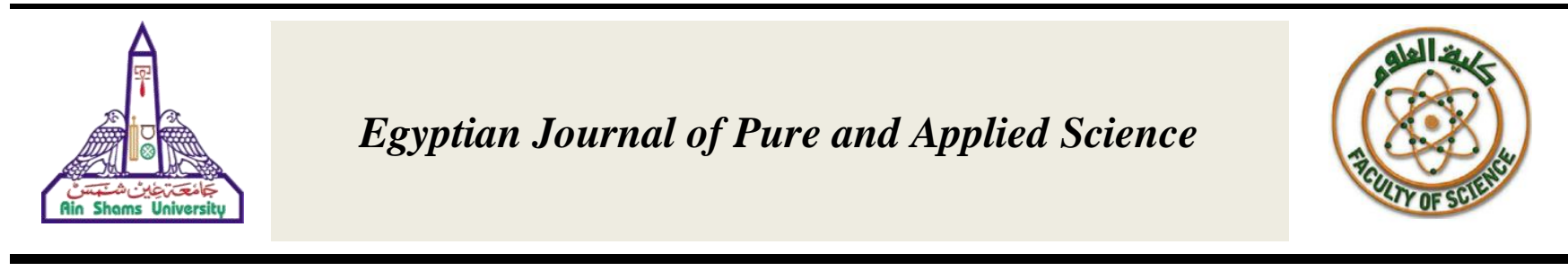

\title{
Potential Effect of Natural Microbial Metabolites as Antimicrobial
} Agents

\author{
Shadia Abdel-Hamid Fathy, Gamila Mohamed Labib Shanab and Eman M. Saleh* \\ Department of Biochemistry, Faculty of Science, Ain Shams University, Abbassia 11566, Cairo, Egypt.
}

ARTICLE INFO

Article history:

Received 06 January 2016

Accepted 09 March 2016

Keywords:

Actinomycetes;

Streptomyces:

Natural antibiotic;

Albino rats.

\begin{abstract}
A B S T R A C T
The present study was an extensive search for the discovery of a new antimicrobial agent from different Streptomyces strains with pronounced activity against Gram +ve and Gram -ve bacteria. The best conditions for its isolation, growth and purification were determined. Using physical and chemical approaches, the molecular formula of this new antibiotic, named A5, was deduced and a molecular structure was proposed. Investigations of the possible mode of action of A5 revealed that it arrested bacterial cell wall synthesis and decreased bacterial intracellular macromolecule content of both $S$. aureus and $E$. coli, as well as acting as an intercalating agent. In addition, biochemical and toxicological effects of A5 on animal cells were investigated. A onetime injection of rats with acute doses of A5 revealed a dose-dependent side effect of this antibiotic on serum glucose, total proteins and lipid profile as well as on liver function, but not renal function, in addition to an effect on the antioxidant system MDA-SOD. These results lead for further studies with lower chronic doses of A5 in order to determine its potential therapeutic use.
\end{abstract}

\section{Introduction}

The resistance of a large number of pathogenic bacteria and fungi to bioactive secondary metabolites in common use is currently an urgent focus of research, and new antifungal and antibacterial molecules are necessary to combat these pathogens. Filamentous soil bacteria belonging to the genus Streptomyces are rich sources of a high number of bioactive natural products with biological activity, which are extensively used as pharmaceuticals and agrochemicals [1], so the identifications of new Actinomycete strains that belong to the genus Streptomyces and partial characterization of the produced antibacterial activities still carry on ${ }^{[2]}$. These bacteria produce about $75 \%$ of the commercially and medically useful antibiotics ${ }^{[3]}$ with approximately $60 \%$ of antibiotics isolated from Streptomyces species [4]

Antibiotics are members of an extremely diverse group of metabolic products known as secondary metabolites, which are typically complex organic molecules that are not essential for normal cell growth and reproduction and are produced only after an organism has established itself in its environment. The interaction between host, microbial pathogen and antimicrobial agent can be considered as a triangle, and any alteration in one side

\footnotetext{
* Corresponding author.

E-mail address: e_ahmed@sci.asu.edu.eg
}

will inevitably affect the two other sides ${ }^{[5]}$. The rapid emergence of antibiotic resistance in pathogenic bacteria has underscored the need for an accelerated approach to the discovery of new antibacterial agents ${ }^{[6]}$. Several research centers around the world are involved in such efforts which resulted in the production of several new members of synthetic compounds such as quinolones ${ }^{[7]}$, carbapenems [8], amphotericin [9], macrolides and antimicrobial peptides ${ }^{[10]}$.

The key to successful chemotherapy against microbes is selective toxicity; that is, an effective antimicrobial agent must be more toxic to a pathogen than to the pathogen's host. Selective toxicity is possible because of differences in structure or metabolism between the pathogen and its host. Typically, the more differences, the easier it is to discover or create an effective antimicrobial agent ${ }^{[11]}$. Side effects of antibiotic treatment fall into three main categories: toxicity, allergies and disruption of normal microflora. The mechanism by which antibiotics exert their toxic effects may be different in each case, for example; different tissues of animals respond differently to oxidative stress depending on the status of their own antioxidant defense system and nature of damaging agents ${ }^{[12]}$. Administration of first generation antibiotics such as tetracycline, chloramphenicol, and streptomycin can cause profound alteration in lipid peroxidation levels in different tissues of rat with decrease in superoxide 
dismutase and catalase activities and increase in the levels of reduced glutathione especially in the kidney [13]. Reported side effects of tetracyclines include hypersensitivity, photosensitivity, neurotoxicity, hepatoxicity, and nephrotoxicity. Gastrointestinal upset, jaundice, liver damage, cardiotoxic effect, severe dyspnea, and anaphylaxis have been reported after administration of macrolides ${ }^{[\mathbf{1 4}]}$.

Although antimicrobial drugs are ideally selectively toxic against microbes and harmless to human, many in fact have toxic side effects such as nausea, vomiting, diarrhea, and abdominal pain. Toxic reactions are usually, but not always, dose dependent and some are irreversible. They do not rely on the patient's immune system. Among antibacterial agents in regular use, for example, polymyxins, aminoglycosides and glycopeptides can be fatally toxic to kidneys, but not all toxic side effects are so serious ${ }^{[15]}$. The $\beta$-lactam antibiotics may cause less toxic reaction but are more common cause of allergic phenomena, varying from short-lived rashes to sever anaphylaxis ${ }^{[16]}$. The drugs that disrupt normal microbiota and their microbial antagonism of opportunistic pathogens may result in secondary infection called "Superinfection". This is why candidacies are so common following antibacterial treatment. It is also the reason for antibiotic-associated diarrhea. For example, long-term use of broad-spectrum antimicrobials such as tetracyclines, clindamycin, penicillins and cephalosporins often results in explosion in the growth rate of Candida albicans in the vagina (vaginitis) or mouth (thrush), and the multiplication of Clostridium difficile in the colon that causes a potentially fatal condition called pseudomembranous colitis, which is a severe form of diarrhea in antibiotic treated patients ${ }^{[17]}$.

So, the overall goal of the present study is to search for new natural antibiotics from various strains of Streptomyces. The most potent antibiotic will be purified and its chemical structure will be characterized. The antimicrobial activities of the selected antibiotic will be investigated against bacterial cells and its probable mode of action will be elucidated. Investigation of the biochemical and toxicological effects of the selected antibiotic on experimental animals will be carried out to evaluate its potential therapeutic use.

\section{Materials and Methods \\ Microbial studies}

\section{Organisms and Culture Conditions}

Different strains of Actinomycetes studied in the present work were isolated from soil samples collected from different governorates in Egypt (Cairo, Giza, Sharkeya and Marsa Matrouh) for their antagonistic properties against different strains of bacterial and fungal species. Biologically active isolates were sub cultured on starch-nitrate agar medium. The sensitive strains of $E$. coli and $S$. aureus were selected to study the mechanism of action of the extracted antibiotic and testing its potency.

\section{Characterization and classification of the selected Actinomycete isolate (Actino. 5)}

The selected Actinomycete isolate (Actino.5) was characterized by studying its morphological and cultural characteristics as well as its biochemical and physiological properties.

\section{Physical and chemical properties of the extracted antibiotic 5(A5)}

Ultraviolet, infrared, mass spectroscopy, elemental analyses and nuclear magnetic resonance (NMR) were performed to determine the molecular weight and the molecular structure of A5. Further chemical tests were carried out to identify the functional groups of the antibiotic.

\section{Biological properties of A5 (Antimicrobial activity)}

The antimicrobial activity of the purified antibiotic was studied against a variety of microbes. These organisms included Gram-positive and Gram-negative bacteria as well as some fungi. The minimum inhibitory concentration (MIC) was determined by the serial agar dilution method. The effects of different $\mathrm{pH}$ values and various incubation periods in addition to effects of different media compositions were investigated in order to attain the optimum production of the antibiotic.

\section{The mode of action of A5 on $S$. aureus and $E$. coli cells}

The effects exerted by different concentrations of the A5 on the growth rate and some biochemical activities of S. aureus and E. coli cells such as acid-soluble phosphorous compounds, total lipids, total proteins, RNA and DNA were studied. Also, the effect of A5 on the accumulation of $\mathrm{N}$-acetylglucosamine in $S$. aureus and $E$. coli cells was examined.

\section{In vitro studies}

Amino acid analysis of the metabolism solution of control and antibiotic-treated S. aureus and E. coli cells was done as previously described ${ }^{[18]}$. The in vitro effect of A5 on thermal denaturation pattern (Tm) of salmon testis DNA was assessed according to the previously described method [19]. SDS-PAGE analysis of the intracellular proteins of $S$. aureus and E. coli cells was performed as previously described ${ }^{[20]}$. The effect of A5 on bacterial cell wall synthesis was examined under electron microscope. Transmission photos of S. aureus and E. coli cells treated with the antibiotic and control were obtained at the Central Laboratory, Faculty of Science, Ain Shams University using Electron Microscope JEOL-JEM 1200 EXII.

\section{In vivo studies}

A total number of 150 adult male Albino rats weighing 140-150g were purchased from Egyptian Organization for Biological Products and Vaccines (Helwan Farm, Egypt). The animals were housed in separated steel cages (5 rats/cage) and maintained in a controlled environment under standard conditions of temperature and humidity. The local committee approved the design of the experiments, and the protocol confirms the guidelines of the National Institute of Health (NIH). 
1. Determination of acute lethal dose (LD100) and median lethal dose (LD50) of A5

A total of 90 adult male Albino rats were used to determine the LD100 and LD50 of the A5 antibiotic. The rats were divided equally into 9 groups representing doses from 39.5 to $1012 \mathrm{mg}$ of the antibiotic/ $\mathrm{kg}$ body weight with an increasing factor of 1.5. The rats were injected i.p. with the A5. Mortality was recorded after 24 hours, and the LD50 was calculated as follows:

$\log \mathrm{LD} 50=\log \mathrm{LD}$ next below $50 \%+(\log$ increasing factor $\mathrm{x}$ proportionate distance).

Proportionate distance $=(50 \%-\%$ mortality next below $50 \%$ ) / (\% mortality above $50 \%$ - \% mortality next below 50\%).

\section{Experimental design}

After determination of the LD50, another set of 60 rats was used for biochemical studies of A5. Rats were divided into 3 equal groups ( $\mathrm{n}=20$ for each) as follows: Group (1); normal healthy rats injected i.p. with saline only, Group (2); normal healthy rats injected i.p. once with $1 / 4 \mathrm{LD} 50$ dose of A5 $(55.25 \mathrm{mg} / \mathrm{kg}$ body weight $)$ and Group (3); normal healthy rats injected i.p. once with $1 / 2$ LD50 dose of A5 (110.5mg/kg body weight). At the end of the experimental period ( 24 hours), food was withheld for 14 hours to provide fasting blood samples. The animals were then sacrificed. Serum and liver samples from different groups of animals were collected.

\section{Biochemical analyses}

Sera of all animals were subjected to the following quantitative determinations: glucose ${ }^{[21]}$, total proteins ${ }^{[22]}$, albumin ${ }^{[23]}$, Alanine aminotransferase (ALT) and Aspartate aminotransferase (AST) [24], Alkaline phosphatase (ALP) ${ }^{[25]}$, creatinine ${ }^{[26]}$, blood urea nitrogen ${ }^{[27]}$, total lipids ${ }^{[28]}$, triglycerides ${ }^{[29]}$ and total cholesterol ${ }^{[30]}$. Another small amount of blood was collected in heparinized tube to obtain plasma samples for the determination of superoxide dismutase enzyme (SOD) ${ }^{[31]}$.

After blood collection, the liver of each animal was excised, rinsed in isotonic sterile saline, blotted dry with filter paper, weighed and then dropped in vials containing ice-cold sterile saline and stored at $-20^{\circ} \mathrm{C}$ for biochemical analysis. The liver homogenate was used for determination of DNA ${ }^{[32]}$, RNA ${ }^{[33]}$, total proteins ${ }^{[34]}$, and malondialdehyde (MDA) concentration ${ }^{[35]}$.

\section{Statistical analysis}

Data was expressed descriptively as percentages for qualitative values and mean \pm standard deviation (SD) for quantitative parametric data. The complied data was computerized and analyzed by SPSS software package, version 14. Student T- test was used for assessment of differences between samples. A level of significance with $\mathrm{p} \leq 0.05$ was considered significant, $\mathrm{p} \leq 0.01$ was considered of high significance and $\mathrm{p}>0.05$ insignificant.

\section{Results}

Fifteen pure Actinomycete isolates were isolated from different soil samples collected from Cairo, Giza, Sharkeya and Marsa Matrouh. These isolates were given serial numbers from 1 to 15 and their antimicrobial activities against different bacterial and fungal strains were examined. Among them Actino.5 strain was selected for further studies.

Characterization and classification of the selected Actinomycete isolate (Actino. 5)

Light microscopic examination of aerial and substrate mycelia and sporophores of the Actino.5 indicated that the sporophores are spiral and branched with a hook end (Photos 1), while electron microscopic examination of spores revealed that the spores are tubular with a smooth surface (Photo 2).

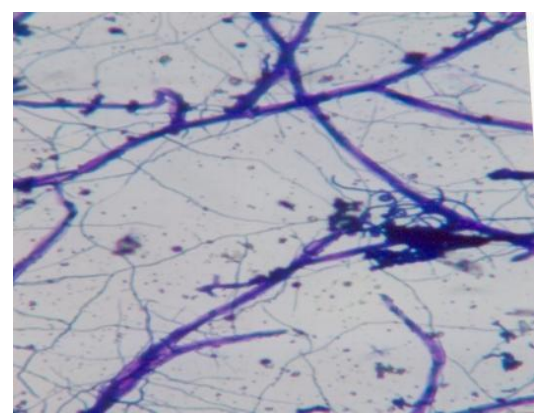

Photo (1): Light micrograph of the sporophores of Actino.5 (x 10,000).

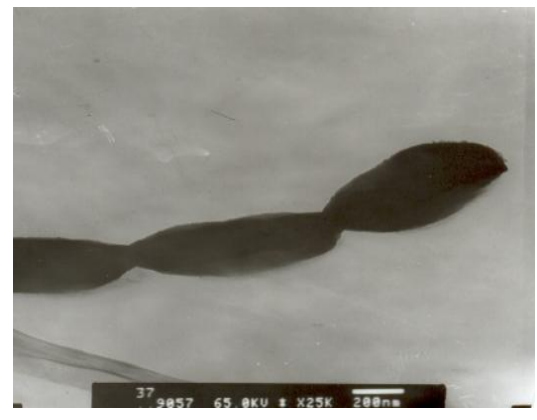

Photo (2): Electron micrograph of the spores of Actino.5 (x 25,000).

\section{Elucidating the supposed structure of A5}

Based on the results of the physical and chemical characterization of $\mathrm{A} 5$, the molecular structure illustrated in Figure (1) was suggested. In addition, acid hydrolysis of A5 followed by chromatographic separation on cellulose paper revealed the absence of carbohydrates, amino acids or organic acid moieties.<smiles>C/C=C(/C)C(O)/C(O)=C/C(C)(O)c1c(Cl)ccc(O)c1C(=O)C(O)/C(O)=C/C(=O)CC(N)=O</smiles>

Fig (1): Suggested molecular structure of A5 (molecular formula: $\mathrm{C}_{23} \mathrm{H}_{29} \mathrm{~N}_{2} \mathrm{O}_{10} \mathrm{Cl}$ and molecular weight: 528). 
Biological properties of A5 (Antimicrobial activity)

Sensitivity of different microorganisms to A5, as well as MIC assays were carried out to select the most sensitive strain to A5 for further investigations. Results showed that A5 had variable antimicrobial activities against Gram +ve and Gram -ve bacteria. The sensitive strains S. aureus NRRL-B-767 and E. coli NRRL-B- 210 were selected for further microbial studies since they were the most affected organisms.

Studies on the mode of action of A5 on S. aureus and E. coli cells

The intracellular components of A5-treated and untreated cells of $S$. aureus and E. coli were separated and quantitatively estimated. The results are summarized in Table (1).

Table 1: Percent change of the cellular components of S. aureus and E. coli cells (mg/100g dry cell wt).

\begin{tabular}{|c|c|c|c|c|c|c|c|c|c|c|c|c|}
\hline Cell & \multicolumn{2}{|c|}{ Phosphorous } & \multicolumn{2}{|c|}{ Total lipids } & \multicolumn{2}{|c|}{ Total proteins } & \multicolumn{2}{|c|}{ RNA } & \multicolumn{2}{|c|}{ DNA } & \multicolumn{2}{|c|}{ NAG } \\
\hline M.O. & S. aureus & E. coli & S. aureus & E. coli & S. aureus & E. coli & S. aureus & E. coli & S. aureus & E. coli & S. aureus & E. coli \\
\hline MIC & $-33.1 \%$ & $-35.9 \%$ & $-16.5 \%$ & $-17.8 \%$ & $-55.2 \%$ & $-43.2 \%$ & $-37.9 \%$ & $-34.9 \%$ & $-35.9 \%$ & $-33.0 \%$ & $+56.8 \%$ & $+28.0 \%$ \\
\hline 2MIC & $-40.0 \%$ & $-38.8 \%$ & $-19.5 \%$ & $-22.5 \%$ & $-62.9 \%$ & $-46.0 \%$ & $-47.2 \%$ & $-41.8 \%$ & $-40.2 \%$ & $-45.8 \%$ & $+77.3 \%$ & $+58.9 \%$ \\
\hline 4MIC & $-47.2 \%$ & $-44.9 \%$ & $-28.6 \%$ & $-26.4 \%$ & $-70.2 \%$ & $-58.5 \%$ & $-54.8 \%$ & $-47.8 \%$ & $-56.7 \%$ & $-51.5 \%$ & $+142.5 \%$ & $+95.7 \%$ \\
\hline
\end{tabular}

MIC, minimum inhibitory concentration; NAG, N-acetyl glucosamine.

Amino acid analysis of untreated and A5-treated $S$. aureus and $E$. coli cells

The amino acid content of untreated and antibiotictreated microorganisms was analyzed by HPLC. Data obtained revealed variable changes for individual amino acids, either increase (glycine, histidine, alanine, methionine and lysine) or decrease (aspartic, glutamic, serine, arginine, proline, tyrosine, valine, isoleucine and leucine).

SDS-PAGE analysis of the intracellular proteins of untreated and A5-treated $S$. aureus and $E$. coli cells Photos ( $3 \& 4)$ show some changes in the density of separated bands of proteins extracted from treated $S$. aureus and treated E. coli cells respectively when compared to untreated cells.

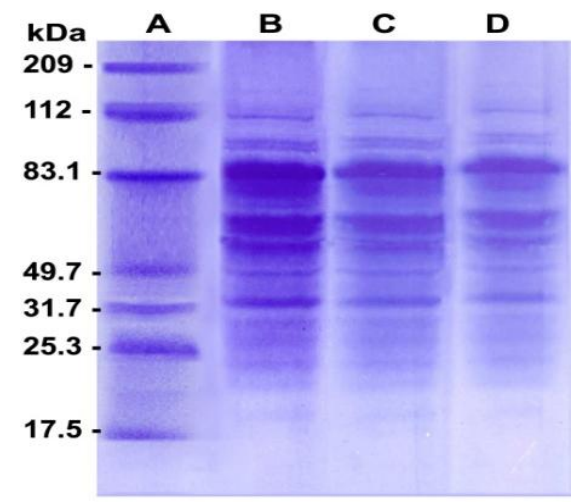

Photo (3): SDS-PAGE analysis of protein extracted from untreated and treated $S$. aureus cells. A) Protein molecular weight marker. B) Untreated $S$. aureus cells. C) Antibiotic-treated $S$. aureus cells with MIC. D) Antibiotic-treated $S$. aureus cells with 2MIC.

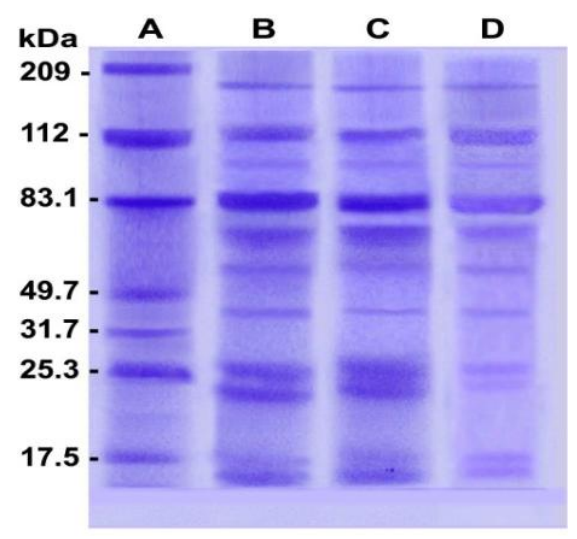

Photo (4): SDS-PAGE analysis of protein extracted from untreated and treated E. coli cells. A) Protein molecular weight marker. B) Untreated E. coli cells. C) Antibiotictreated E. coli cells with MIC. D) Antibiotic-treated E. coli cells with $2 \mathrm{MIC}$.

Effect of A5 on the thermal denaturation $\left(T_{m}\right)$ of Salmon testis DNA

The effect of different concentrations of A5 $(5-20 \mu \mathrm{g} / \mathrm{ml})$ on the thermal denaturation pattern of salmon testis DNA was studied. A5 caused an elevation in the Tm of salmon testis DNA, and the rise was concentration-dependent, where the $\mathrm{Tm}$ increased from $75^{\circ} \mathrm{C}$ to $77.5^{\circ} \mathrm{C}, 80^{\circ} \mathrm{C}$, $82.5^{\circ} \mathrm{C}$ and $85^{\circ} \mathrm{C}$ with the addition of $5,10,15$, and 20 $\mu \mathrm{g} / \mathrm{ml}$ of A5 antibiotic, respectively.

Electron micrographs of $\mathrm{A5}$-treated and untreated $S$. aureus and $E$. coli cells

Transmission electron microscopic photos of untreated $S$. aureus NRRL-B-767 and E. coli NRRL-B-210 cells show that the normal rounded shape of cocci $S$. aureus cells 
and normal rod shape of bacilli E. coli cells (Photos 5 \& 7). While Photos (6 \& 8) show the rapture of the cells treated with A5 with the extrusion of the cytoplasm from the cell in $S$. aureus and also some damaged regions of the cell wall of $E$. coli.

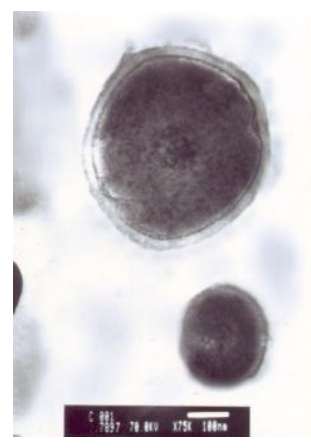

Photo (5): Transmission electro-micrograph of untreated S. aureus NRRL- B- 767 (x 75.000).

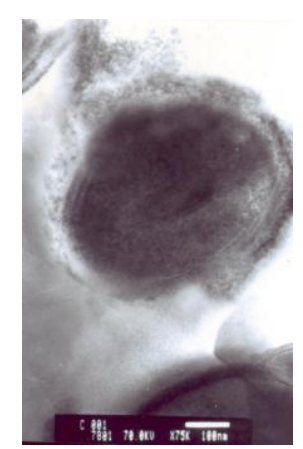

Photo (6): Transmission electro-micrograph of A5treated S. aureus NRRL- B- 767 (x 75.000).

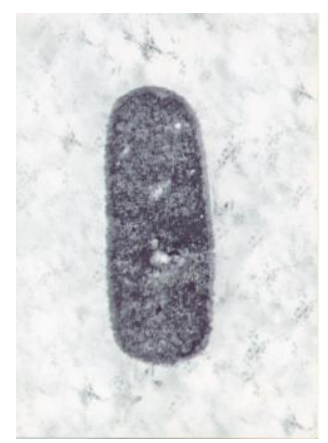

Photo (7): Transmission electro-micrograph of untreated E. coli NRRL- B- 210 (x 75.000).

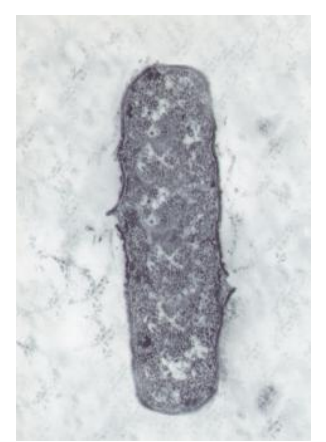

Photo (8): Transmission electro-micrograph of A5treated E. coli NRRL- B- 210 (x 75.000).

\section{Animal studies \\ Blood parameters}

The results of the pilot study of the effect of A5 on experimental animals revealed that, the acute lethal dose (LD100) was $1012 \mathrm{mg} / \mathrm{kg}$ body weight, while the median lethal dose (LD50) was $221.3 \mathrm{mg} / \mathrm{kg}$ body weight for the A5 antibiotic after i.p. injection in Albino rats.

The results presented in Table (2) summarized the effects of A5 on different serum biomarkers of rats. Results revealed that serum glucose was significantly decreased by $(-9.22 \%)$ and $(-24.35 \%)(\mathrm{p}<0.001)$ in rats treated with two different doses of A5 (LD50/4= 55.33 $\mathrm{mg} / \mathrm{kg}$ body weight and LD50/2= $110.5 \mathrm{mg} / \mathrm{kg}$ body weight), respectively, when compared to rats of the control group. Serum creatinine showed no significant difference in animals treated with the first dose of A5 (LD50/4) ( $>>0.05)$ when compared with control. While the same parameter showed a significant decrease in animals treated with the second dose of A5 (LD50/2) $(\mathrm{p}<0.001)$ when compared with control. Serum blood urea nitrogen (BUN) was significantly decreased by ($10.69 \%)$ and $(-19.32 \%)(\mathrm{p}<0.001)$ for LD50/4 and LD50/2 doses, respectively.

Results clearly indicate that, the levels of total serum protein was significantly decreased $(\mathrm{p}<0.001)$ by $(-$ $7.61 \%)$ and $(-22.25 \%)$ in rats treated with both doses of A5, respectively, when compared to the animals of control group, also the concentration of albumin was significantly decreased $(\mathrm{p}<0.001)$ by $(-8.91 \%)$ and $(-$ $19.08 \%)$ in rats treated with both doses of A5, respectively. The level of globulin showed a significant decrease in rats treated with $\mathrm{LD}_{50} / 4$ dose of $\mathrm{A} 5(\mathrm{p}<0.05$, $-5.86 \%$ reduction) when compared with control, while globulin level was significantly decreased in rats treated with $\mathrm{LD}_{50} / 2$ dose $(\mathrm{p}<0.001,-26.90 \%$ reduction) when compared with control. The A/G ratio was not significantly different in rats treated with $\mathrm{LD}_{50} / 4$ dose of A5 ( $>0.05)$, however it shows a significant increase in rats treated with $\mathrm{LD}_{50} / 2$ of $\mathrm{A} 5(\mathrm{p}<0.05)$ when compared with control.

Liver function tests showed that a significant increase $(\mathrm{p}<0.001)$ in the levels of AST $(+43.16 \%$ and +68.32 for $\mathrm{LD}_{50} / 4$ - and $\mathrm{LD}_{50} / 2$ - treated rats, respectively), ALT $\left(+26.12 \%\right.$ and $+47.62 \%$ for $\mathrm{LD}_{50} / 4-$ and $\mathrm{LD}_{50} / 2-$ treated rats, respectively) and ALP $(+27.55 \%$ and $+61.17 \%$ for $\mathrm{LD}_{50} / 4$ - and $\mathrm{LD}_{50} / 2$ - treated rats, respectively) after injection of both doses of A5 when compared with control group. Results also clearly indicated that both doses of A5 had a significant increasing effect on serum triacylglycerols $(\mathrm{p}<0.001)$ by $(+23.6 \%)$ for $\mathrm{LD}_{50} / 4$ and $(+77.8 \%)$ for $\mathrm{LD}_{50} / 2$. The $\mathrm{LD}_{50} / 4$ dose caused a significant increase in total lipids and total cholesterol $(\mathrm{p}<0.05)$ by $(+7.98 \%)$ and $(+2.65 \%)$, respectively, while the $\mathrm{LD}_{50} / 2$ dose resulted in a significant increase of those parameters $(\mathrm{p}<0.001)$ by $(+22.71 \%)$ and $(+4.63 \%)$, respectively. So, both doses of A5 caused a significant increase in total lipids and total cholesterol; the increasing effect was dose-dependent $(\mathrm{p}<0.05$ and $\mathrm{p}<0.001$ for $\mathrm{LD}_{50} / 4$ and $\mathrm{LD}_{50} / 2$, respectively). 
Table 2: Levels of blood parameters in control, $\mathrm{LD}_{50} / 4$ - and $\mathrm{LD}_{50} / 2$ - treated rats.

\begin{tabular}{|c|c|c|c|c|c|}
\hline \multirow{2}{*}{ Groups } & Control & \multicolumn{2}{|c|}{ LD $_{\mathbf{5 0}} / \mathbf{4}$ - treated } & \multicolumn{2}{c|}{ LD $_{\mathbf{5 0}}$ /2- treated } \\
\cline { 2 - 6 } & Mean \pm SD & Mean \pm SD & $P$ value & Mean \pm SD & $P$ value \\
\hline Glucose (mg/dl) & $84.19 \pm 4.37$ & $77.32 \pm 3.85$ & $<0.001$ & $63.69 \pm 5.57$ & $<0.001$ \\
\hline Creatinine (mg/dl) & $0.59 \pm 0.05$ & $0.56 \pm 0.04$ & N.S. & $0.53 \pm 0.03$ & $<0.001$ \\
\hline BUN (mg/dl) & $21.22 \pm 0.77$ & $18.95 \pm 1.00$ & $<0.001$ & $17.12 \pm 0.66$ & $<0.001$ \\
\hline Total proteins (g/dl) & $6.83 \pm 0.31$ & $6.31 \pm 0.46$ & $<0.001$ & $5.31 \pm 0.31$ & $<0.001$ \\
\hline Albumin (g/dl) & $3.93 \pm 0.34$ & $3.58 \pm 0.21$ & $<0.001$ & $3.18 \pm 0.27$ & $<0.001$ \\
\hline Globulin (g/dl) & $2.9 \pm 0.18$ & $2.73 \pm 0.38$ & $<0.05$ & $2.12 \pm 0.19$ & $<0.001$ \\
\hline A/G ratio & $1.36 \pm 0.19$ & $1.31 \pm 0.18$ & $\mathrm{~N} . \mathrm{S}$. & $1.5 \pm 0.17$ & $<0.05$ \\
\hline AST (IU/L) & $35.38 \pm 3.49$ & $50.65 \pm 3.48$ & $<0.001$ & $59.55 \pm 2.79$ & $<0.001$ \\
\hline ALT (IU/L) & $48.45 \pm 5.97$ & $58.08 \pm 4.75$ & $<0.001$ & $67.98 \pm 3.69$ & $<0.001$ \\
\hline ALP (IU/L) & $56.11 \pm 4.71$ & $71.57 \pm 4.48$ & $<0.001$ & $90.43 \pm 7.94$ & $<0.001$ \\
\hline Total lipids (mg/dl) & $161.92 \pm 14.34$ & $174.85 \pm 13.93$ & $<0.05$ & $198.69 \pm 9.16$ & $<0.001$ \\
\hline Total cholesterol (mg/dl) & $84.86 \pm 3.75$ & $87.11 \pm 1.82$ & $<0.05$ & $88.79 \pm 3.50$ & $<0.001$ \\
\hline Triacylglycerols (mg/dl) & $77.94 \pm 5.33$ & $96.35 \pm 5.35$ & $<0.001$ & $138.58 \pm 6.57$ & $<0.001$ \\
\hline Plasma SOD (IU/L) & $50.04 \pm 3.50$ & $58.59 \pm 5.76$ & $<0.001$ & $64.67 \pm 3.08$ & $<0.001$ \\
\hline
\end{tabular}

N.S: Non- significant, LD50 /4=55.33 $\mathrm{mg} / \mathrm{kg}$ body weight, LD50 $/ 2=110.65 \mathrm{mg} / \mathrm{kg}$ body weight, $\mathrm{p}$ is significant at $\leq 0.05$.

The effect of A5 on the plasma level of antioxidant enzyme (SOD) indicated that there was a significant elevation in SOD level in plasma sample $(\mathrm{p}<0.001)$ of A5- treated rats by $(+17.2 \%)$ for $\mathrm{LD}_{50} / 4$ and $(+29.4 \%)$ for $\mathrm{LD}_{50} / 2$ when compared to control group.

\section{Liver tissue parameters}

Results of liver analyses presented in Table (3) showed that both doses of A5 resulted in a significant decrease in the levels of those parameters $(\mathrm{p}<0.001)$. The percentage of inhibition in LD50/4- and LD50/2- treated rats were $(-12.82 \%)$ and $(-35.97 \%)$ in case of total protein content, $(-13.66 \%)$ and $(-30.87 \%)$ in case of DNA, and finally $(-18.88 \%)$ and $(-31.96 \%)$ in case of RNA content, respectively. The effect of A5 on lipid peroxidation product (MDA) indicated that there was a significant elevation in MDA level in liver tissue $(\mathrm{p}<0.001)$ of A5-treated rats by $(+17.48 \%)$ and $(+22.61 \%)$ for $\mathrm{LD}_{50} / 4-$ and $\mathrm{LD}_{50} / 2$ doses, respectively, when compared to control group.

Table 3: Levels of liver tissue parameters in control, $\mathrm{LD}_{50} / 4$ - and $\mathrm{LD}_{50} / 2$ - treated rats.

\begin{tabular}{|c|c|c|c|c|c|}
\hline \multirow{2}{*}{ Groups } & Control & \multicolumn{2}{|c|}{ LD $_{\text {50 }} /$ 4- treated } & \multicolumn{2}{c|}{ LD $_{\mathbf{5 0}} /$ 2- treated $^{-}$} \\
\cline { 2 - 6 } & Mean \pm SD & Mean \pm SD & $P$ value & Mean \pm SD & $P$ value \\
\hline Total proteins (mg/g) & $155.00 \pm 3.80$ & $135.13 \pm 2.36$ & $<0.001$ & $99.25 \pm 3.05$ & $<0.001$ \\
\hline DNA(mg/g) & $3.66 \pm 0.41$ & $3.16 \pm 0.29$ & $<0.001$ & $2.53 \pm 0.35$ & $<0.001$ \\
\hline RNA(mg/g) & $8.48 \pm 0.47$ & $6.88 \pm 0.49$ & $<0.001$ & $5.77 \pm 0.45$ & $<0.001$ \\
\hline MDA (n.mole/g) & $41.36 \pm 0.90$ & $48.59 \pm 1.55$ & $<0.001$ & $50.71 \pm 1.75$ & $<0.001$ \\
\hline
\end{tabular}

$\mathrm{LD}_{50} / 4=55.33 \mathrm{mg} / \mathrm{kg}$ body weight, $\mathrm{LD}_{50} / 2=110.65 \mathrm{mg} / \mathrm{kg}$ body weight, $p$ is significant at $\leq 0.05$.

\section{Discussion}

Although the majority of bacterial infections are under control, there is still a great demand for new therapeutic agents to fill the remaining gaps, or to combat pathogens that have developed resistance to the drug ${ }^{[36]}$. Antibiotic elaborated by the microorganisms were thought to play an important role in the suppression of the pathogen growth. Streptomyces is the most commercially important bacterium for human and veterinary medicine because it is one of the main producers of antibiotics ${ }^{[37]}$. The present study aimed to screen the antibioticproducing Actinomycetes isolated from Egyptian soil samples, fifteen organisms have been isolated. The isolates were tested for antagonistic activities against different strains of Gram-positive and Gram-negative bacteria and fungi. The most potent Actinomycete culture found among the tested cultures is the culture given the abbreviated name (Actino.5). The selected Actinomycete was subjected to further studies including morphological properties, cultural characteristics and potency for antibiotic production. A5 was extracted from fermented broth of isolated Streptomyces.

Studies on bacterial cultures for elucidating the main target site of the action of A5 using three different conc- 
entrations of A5 (MIC, 2MIC and 4 MIC) demonstrated a pronounced decrease in the growth rate of $S$. aureus and $E$. coli cells. Consequently, further studies of the effect of different concentrations of A5 on the cellular macromolecules of $S$. aureus and $E$. coli cells were performed. The results clearly indicated that total proteins, RNA, DNA, and acid-soluble phosphorous contents of $S$. aureus and E. coli cells were significantly decreased by the effect of A5 at the different concentrations while a less effect was detected on total lipid contents. Such decreases in the total lipids content of bacteria treated with A5 have been attributed to a variety of modes of action including effect on permeability of the cell membrane, biosynthesis of fatty acids, interaction with lipids and proteins of cell membrane or formation of pore-like structure of cell membrane ${ }^{[38]}$. Such a decrease to the antibiotic property of expanding membrane proteins, resulting in conformational changes of lipid and protein contents which in turn may affect the growth rate of the bacterial cells ${ }^{[39]}$. Also, the remarkable decrease in total proteins content was parallel to the significant decrease in both DNA and RNA contents which may be due to the interaction between the protein synthesis and the ribosomes ${ }^{[40]}$.

Other reasons for the inhibition or killing of the examined bacterial cells may be due to the effect of A5 on bacterial cell wall synthesis, as investigated and confirmed by the accumulation of $\mathrm{N}$-acetylglucosamine, either by inhibition of peptidoglycan synthesis or by preventing the incorporation of amino acids or cell wall precursors into cell wall ${ }^{[41]}$. Also, analysis of the amino acid content by HPLC technique showed the accumulation of certain amino acids which may be due to the possible action of A5 as a transpeptidase inhibitor in the process of peptidoglycan synthesis, resulting in the inability of glycine, lysine and alanine to be incorporated into cell wall ${ }^{[42]}$. The morphological effects exerted on $S$. aureus and $E$. coli cells by the action of A5 were clearly indicated by electron micrograph photos, which showed rapture of the cells treated with A5 with the extrusion of the cytoplasm from both bacterial species. Growth of the bacterial envelope occurred by two mechanisms, one responsible for lateral wall formation and the other for septum formation. It has been speculated that, when only one of these mechanisms is inhibited, the cell can survive for a while since the other mechanism allows surface expansion, which creates additional intracellular room for the newly synthesized molecule resulting in the formation of filamentous shape rather than the wild type cocci. On the contrary, the inhibition of both mechanisms would have a more rapid bactericidal effect since it deprives the cell from any chance for protecting the increasing cytoplasmic content. On the other hand, some antimicrobial agents prevent cell division without inhibiting growth, with the result that abnormally elongated cells are developed ${ }^{[43]}$. Another strong reason for the inhibition of bacterial growth by the action of A5 may be due to the intercalation effect of A5 between the strands of bacterial DNA. The results presented in this study clearly indicated that A5 increased the $T_{m}$ of Salmon testis DNA. It seems likely that A5 probably exerts a secondary effect through inserting itself between the DNA strands. This behavior of A5 is similar to that of a classical intercalating compound as ethidium bromide ${ }^{[44]}$.

Toxicity studies were carried out in the present study in order to establish an initial dose level for subsequent studies as well as to determine toxic manifestations of the antibiotic under test on experimental Albino rats. The $\mathrm{LD}_{50}$ of A5 was found to be $221.3 \mathrm{mg} / \mathrm{kg}$ body weight. As illustrated from the results, A5 caused a highly significant decrease in serum glucose of A5-treated rats as different antibiotics have been associated with hypoglycemia such as levofloxacin ${ }^{[45-46]}$, clarithromycin ${ }^{[47]}$, bacitracin ${ }^{[48]}$ and tetracycline ${ }^{[49]}$.

Also, the present results indicated a significant decrease in the level of serum creatinine and blood urea nitrogen but within normal ranges when compared with untreated control rat group, thus suggesting the possible safety of A5 on renal function. Several antimicrobial drugs such as cefonicid, ofloxacin and gentamycin have no significant effects on renal function ${ }^{[50]}$. However, unlike A5, many antibiotics can lead to an increase in serum creatinine and/or blood urea nitrogen levels (nephrotoxicity) ${ }^{[51]}$.

Treatment of rats with A5 caused hypoalbuminemia and hypoproteinemia in general, which may be attributed to liver inability to synthesize proteins at normal rates or decrease in plasma volume because of water loss and exchange of individual polypeptides ${ }^{[52]}$. Another reason for lowered levels of total proteins may be due to the effect of some antibiotics (such as aminoglycosides) that inhibit protein synthesis by interacting with the ribosomes ${ }^{[40]}$.

A5 treatment showed a highly significant increase in liver enzymes ALT, AST and ALP when administered in different doses when compared with control group. Several antibiotics can cause severe hepatic injury with some increasing or decreasing in liver enzyme activity levels ${ }^{[53]}$. Hepatotoxicity is a significant complication of therapeutic drug use such as in case of using aminoglycosides (tobramycin) ${ }^{[54]}$, sulfamethoxazole/ trimethoprim combination, tetracycline and oxacillin ${ }^{[55]}$. Some morphological changes are known, depending on the target cell type; acute or chronic hepatitis, fatty acid liver disease (after tetracyclines treatment for long time), gallstones (after ceftriaxone treatment), cholestatic type acute or chronic liver damage with or without inflammation, or mixed forms of liver injury ${ }^{[56]}$. A5 showed a highly significant increase in serum total lipids, triacylglycerols, and total cholesterol in comparison with untreated control rat group. These observations of hyperlipidemia and hypercholesterolemia can lead to the possibility of these animals developing cardiovascular disease (CVD) by promoting atheroma development in arteries (atherosclerosis) ${ }^{[57]}$. 
Concerning the results of liver samples, it was observed that rats treated with A5 showed a significant decrease in liver total proteins, DNA and RNA contents comparing to control group. So, this decrease in the protein content may be attributed to the alterations occurring in the DNA of the cells and/or the direct effect on the process of its synthesis within the cells. Also, the decrease in liver RNA content may be due to decrease in RNA polymerase activity, or may be due to decrease in the synthesis of RNA ${ }^{[52]}$. Another study proposed that, lowering the rate of DNA synthesis is a result of decreasing or inhibition in the activity of the enzymes which regulate the synthesis of DNA ${ }^{[58]}$. Also, Slater et al. [59] suggested that antimicrobial agents might interfere with metal ions by forming complexes with them and preventing them from incorporation into metalloproteins necessary for DNA synthesis.

Finally; the results obtained by the action of A5 on antioxidant system obviously showed that, A5 had a highly significant capacity to elevate plasma levels of SOD enzyme and MDA level in liver tissue. On the other hand, rifamycins can suppress the de novo synthesis of Mn-SOD and also ciprofloxacin antibiotics can induce the production of $\mathrm{O}_{2}^{-}$leading to high oxidative stress due to lowering the activity of SOD ${ }^{[\mathbf{6 0}]}$. Lacking of SOD develops a wide range of pathologies, including hepatocellular carcinoma ${ }^{[61]}$, acceleration of muscle mass loss ${ }^{[62]}$ and a reduced lifespan ${ }^{[63]}$. Working on tertracycline antibiotics proved that tetracyclines led to development of oxidative stress which is obviously indicated by the increase in lipid peroxidation and moderate decrease in SOD and catalase activities ${ }^{[13]}$. Many studies have demonstrated the ability of aminoglycosides to facilitate the generation of oxygen free species where, despite their beneficial effects as antibacterial therapy, they have considerable nephrotoxic and ototoxic side effects ${ }^{[64]}$. As reported by Yazar et al. ${ }^{[65]}$ streptomycin and gentamycin caused increases in renal MDA levels, so aminoglycoside-induced nephrotoxicity is related to lipid peroxidation and at high dosage or for a long time, tissue injury may occur in the kidney.

In conclusion, a new potent antibiotic (A5) was isolated and purified from a Streptomyces species. A5 affects cell wall synthesis and intracellular macromolecule content of both Gram +ve and Gram -ve bacteria. Regarding its effect on animal cells, A5 caused some minimal side effects at the acute lower dose used, while, at the higher acute dose, a more pronounced effect was observed. Further studies with A5 are needed in order to elucidate its mechanism of action on bacterial cells in more details, as well as studies with lower chronic doses of A5 in order to determine its potential therapeutic use.

\section{References}

1) Mellouli L., Mehdi Ben Ameur R., Fourati Ben Fguira L., Sioud S., Karray-Rebai I. and Bejar S.
(2005). Antimicrobial activities from new isolated Stroptomyces strains. International Conferences on environmental, industrial and applied microbiology.

2) Boudjella H., Bouti K., Zitouni A., Mathieu F., Lebrihi A. and Sabaou N. (2007). Isolation of partil characterization of pigment-like antibiotics produced by a new strain of Streptosporangium isolated from an Algerian soil. J. Applied Microbiology, 10:13261372.

3) Miyadoh S. (1993). Research on antibiotic screening in Japan over the last decade: A producing microorganism approach. Actinomycetologica, 7(2): 100-106.

4) Tanaka Y. T. and Mura S.O. (1993). Chemistry of natural compounds. Anuu. Rev. microbial., 47: 5787.

5) Bauman R. W., Machunis-Masuoka E. and Tizard I. (eds.), (2004). "Characterizing and classifying prokaryotes" In "Microbiology". Pearson Benjamin Cummings, San Francisco, U.S.A. Chapter 11, p: 313-339.

6) Watanabe T., Hashimoto Y., Yamamoto K., Hirao K., Ishihama A., Hino M. and Utsumi R. (2003). Isolation and characterization of inhibitors of the essential histidine kinase, YycG in Bacillus subtilis and Staphylococcus aureus. J. Antibiotics, 56(12): 1045-1052.

7) Schentag J. J. (2000): "Sparfloxacin: a review". Clin. Ther., 22(4): 372-387.

8) Kawamoto I., Shimoji Y., Kanno O., KojimaK., Ishikawa K., Matsuyama E., Ashida Y., Shibayama T., Fukuoka T. and Ohya S. (2003). Synthesis and structure-activity relationships of noval parenteral carbapenems, CS (R-115685) and related compounds containing an amidine moiety. J. Antibiotics, 56(6): 565-579.

9) Gruszecki W. I., Gagos M., Herec M. and Kernen P. (2003). Organization of antibiotic amphotericin B in model lipid membrane. J. Cell Mol. Biol., 8(1): 161-170.

10) Pini A., Giuliani A., Falciani C., Runci Y., Ricci C., Lelli B., Malossi M., Neri P., Rossolini G. M. and Bracci L. (2005). Antimicrobial activity of noval dendrimeric peptides obtained by phage display selection and rational modification. J. Antimicrobials Agents and Chemotherapy, 49(7): 2665-2672.

11) Prescott L. M., Harley J. P., and Klein D. A. (eds.), (2001). In "Microbiology". Fifth edition, Library of Congress Cataloging-in-Publication Data, New York, p: 65-89.

12) Yazar E., Oztekin E., Sivrikaya A., Col R., Elmas M. and Bas A. L. (2004). Effects of different doses of tilmicosin on malondialdehyde and glutathione concentrations in mice. J. Acta Veterinary Brno, 73: 69-72.

13) Shewade Y., Tirth S. and Bhonde R. R. (2001). Pancreatic islet-cell viability, functionality and oxidative status remain unaffected at pharmacological 
concentrations of commonly used antibiotics in vitro. J. Bioscience, 26(3): 349-355.

14) Kucers A., Crowe S. M., Grayson M. L., and Hoy J. F. (1997). The use of antibiotics: a clinical review of antibacterial, antifungal, and antiviral drugs. Fifth edition, Butterworth-Heinemann, Oxford, United Kingdom.

15) Kim A., James A., Thaddeus B., Carole A., Minion F. and Michael J. (2000). In "Virulence Mechanisms of Bacterial Pathogens". Third edition, Library of Congress Cataloging-in-Publication Data, New York, American Society for Microbiology.

16) Patrick R., Ellen J., Michael A., Fred C. and Robert H. (eds.), (1999). In "Manual of Clinical Microbiology". Seventh edition, Library of Congress Cataloging-in-Publication Data, New York, American Society for Microbiology.

17) Inglis T. J. (1996). In "Microbiology and Infection". Churchill Livingstone. Chapter 4, p: 3238.

18) Cohen S., Meys M. and Tarvin T. (1989). A manual of advanced techniques for amino acid analysis. Millipore, U.S.A.

19) Nagai K., Yamaki H., Suzuki H., Tanaka N. and Umezawa H. (1969). Decrease of melting temperature and single strand scission of DNA by Bleomycin in the presence of 2-mercaptoethanol. J. Biochem. Biophys. Acta., 165: 179.

20) Laemmli U. K. (1970). Cleavage of structural proteins during the assembly of the head of bacteriophage T4. J. Nature, 227: 680-685.

21) Trinder P. (1969). Determination of glucose in blood using glucose oxidase with an alternative oxygen acceptor. Ann. Clin. Biochem., 6: 24-28.

22) Henry R. J. (1968). Clinical chemistry principles and technics. Harper \& Row, New York, p: 197.

23) Doumas B. T., Watson W. A. and Biggs H. G. (1971). Albumin standards and the measurement of serum albumin wiyh bromocresol green. Clin. Chim. Acta., 31: 87-96.

24) Reitman S. and Frankel S. (1957). Colorimeteric determination of GOT and GPT activity. Amer. J. Clin. Path., 28: 56-63.

25) Bessey O. A., Lowry O. H. and Brock M. J. (1946). A method for the rapid determination of alkaline phosphatase with five cubic millimeters of serum. J. Biol. Chem., 164: 321-329.

26) Henry R. J. (1974). Clinical chemistry: principles and techniques. Second edition, Harper and Row, p: 682-695.

27) Patton C. J. and Crouch S. R. (1977). Spectrophotometeric and kinetics investigation of the Berthelot reaction for the determination of ammonia. Anal. Chem., 49: 464-469.

28) Knight J. A., Anderson S. and Rawle J. M. (1972). Chemical basis of the sulfo-phosphovanillin reaction for the estimation of total serum lipids. J. Clin. Chem, 18(3): 199-202.

29) Allain C. C., Poon L. S., Chan C. S. G., Richmond W. and Fu P. C. (1974). Enzymatic det- ermination of the total serum cholesterol. Clin. Chem., 20: 470-475.

30) Jacobs N. J. and VanDenmark P. J. (1960). The purification and properties of the $\alpha$ glycerophosphate-oxidizing enzyme of Streptococcus faecalis 10C1. Arch. Biochem. Biophysc., 88(2): 250-255.

31) Marklund S. and Marklund G. (1974). Involvement of the superoxide anion radical in the autoxidation of pyrogallol and a convenient assay for superoxide dismutase. Eur. J. Biochem., 47: 469-474.

32) Dische Z., Chargaff E. and Davidson I. N. (eds.), (1955). In "The nucleic acids: chemistry and biology". Academic Press, New York, Part I. Chapter 6, p: 250 .

33) Merchant D. J., Kahn R. H. I. and Murphy W. H. (eds.), (1969). In "Hand book of cell organ culture". Second edition, Mincecopolis, Burgess Publishing Company. Chapter 18, p: 154.

34) Markwell K. M., Hass S. M., Berber L. I. and Tolbert N. E. (1978). A modification of the lowrry procedure to simplify protein determination in membrane and lipoprotein samples". Anal. Biochem., 87: 206-211.

35) Esterbauer H. and Chesseman K. H. (1990). Detremination of aldehydic lipid peroxidation products: Malonaldehyde and 4-hydroxynonenal. Methods of Enzymology, 186: 407-421.

36) Lee K. H., Lee D. G., Park Y., Kang D., Shin S. Y., Hahm K. and Kim Y. (2006): Interactions between the plasma membrane and the antimicrobial peptide HP (2-20) and its analogues derived from Helicobacter pylori. J. Biochem., 394: 105-114.

37) Todar K. (2006). "Atimicrobial agents used in treatment of infectious diseases", In "Bacteriology". Forth edition, free text book on line, www.textbookofbacteriology.net.

38) Novo D. J., Perlmutter N. G., Hunt R. H. and Shapiro H. M. (2000). Multiparameter flow cytometric analysis of antibiotics effects on membrane potential, membrane permeability, and bacterial counts of S.aureus and Micrococcus luteus. J. Antimicrobial agents and Chemotherapy, 44(4): 827-834.

39) Axelsen P. H. (2007). A chaotic pore model of polypeptide antibiotic action. J. Biophys., 10: 1529.

40) Madigan M., Martinko J. and Parker J. (2003). In "Biology of microorganisms". 10 $0^{\text {th }}$ edition, Pearson Education, Inc. Chapter 20, p: 695-725.

41) Projan S. J. (2002). New (and not so new) antibacterial targets-from where and when will the noval drugs come? Curr. Opin. Pharmacol., 2: 513522.

42) Buurman E. T., Johnson K. D., Kelly R. K. and MacCormack K. (2006). Different Modes of Action of Naphthyridones in Gram-Positive and GramNegative Bacteria. J. Antimicrobial Agents and Chemotherapy, 50(1): 385-387.

43) Dai G., Cheng N., Dong L., Muramatsu M., Xiao S., Wang M. and Zhu D. (2005). Bactericidal and 
morphological effects of NE-2001, a novel synthetic agent directed against Helicobacter pylori. J. Antimicrobial Agents and Chemotherapy, 49(8): 3468-3473.

44) Kemsley J. N., Zaleski K. L., Chow M. S., Decker A., Shishova E. Y., Wasinger E. C., Hedman B., Hodgson K. O. and Solomon E. (2004). Spectroscopic studies of the interaction of ferrous bleomycin with DNA. J. Am. Chem. Soc., 125(36): 10810-10821.

45) Brett A. S. (2006). Gatifloxacin appears to cause both hypoglycemia and hyperglycemia. J. Watch General Medicine, 30: 354.

46) Wang S. and Rizvi A. (2006). Levofloxacininduced hypoglycemia in a nondiabetic patient. American Journal of the Medical Science, 331(6): 334-335.

47) Bussing R. and Gende A. (2002). Severe hypoglycemia from clarithromycin- sulfonylurea drug interaction. Diabetes Care J., 25(9): 1659-1668.

48) Liu H., Tang R., Pan W. S. and Zhang Y. (2003). Potential utility of various protease inhibitors for improving the intestinal absorption of insulin in rats. J. Pharmacy and Pharmacology, 55(11): 1523-1529.

49) Basaria S., Braga M. and Tabb-Moore W. (2002). Doxycycline-induced hypoglycemia in a nondiabetic young man. South. Med. J., 95(11): 1353-1354.

50) Chong C. Y., Tan A. S., Ng W., Tan-Kendrick A., Balakrishnan A. and Chao S. M. (2003). Treatment on urinary tract infection with gantamicin once or three times daily. Acta. Paediatr., 92(3): 291-296.

51) Tan K. H., Mulheran M., Knox A. J. and Smyth A. R. (2003). Aminoglycoside prescribing and surveillance in cystic fibrosis. Am. J. Respir. Crit. Care Med., 167: 819-823.

52) Farombi E., Nwankwo J., Wara S., Odutola B. and Emerole G. (2000). Chloramphenicol and ampicillin-induced changes in rat hepatic esterase and amidase activities. Bioscience Reports, 20(1): 13-19.

53) Giboney P. T. (2005). Mildy elevated liver transaminase levels in the asymptomatic patient. American Family Physician, 71(6): 1105-1110.

54) Nisly S. A. (2007). Tobramycin-induced hepatotoxicity. The Annals of Pharmacotherapy, 41(12): 2061-2065.

55) Brown S. J. and Desmond P. V. (2002). Hepatotoxicity of antimicrobial agents. Semin. Liver
Dis., 22(2): 157-167.

56) Kasper H. U., Drebber U., Hirsch I. and Dienes H. P. (2007). Morphology of drug induced liver damage. J. Patholo., 27(3): 175-181.

57) Beucler I. and Turpin G. (2001). Metabolism of atherogenic lipoproteins. Ann. Med. Inter. (Paris), 152(3): 158-161.

58) Heritage J., Evans E. and Killington R. (2000). In "Microbiology in action". Second edition. Cambridge University Press. Chapter 8, p: 247-266.

59) Slater J. P., Mildvan A. S. and Loeb L. A. (1971). Zinc in DNA polymerases. Biochem. Biophys. Res. Commun., 44(1): 37-43.

60) Becerra M. C., Eraso A. J. and Albesa I. (2003). Comparison of oxidative stress induced by ciprofloxacin and pyoverdin in bacteria and in leukocytes to evaluate toxicity. Luminesence, 18(6): 334-340.

61) Elchuri S., Oberley T. D., Qi W., Eisenstein R. S., Roberts L. J., Remmen H. V., Epstein C. and Huang T. (2005). Cu,Zn-SOD deficiency leads to persistent and widespread oxidative damage and hepatocarcinogenesis later in life. Oncogene, 24: 367-380.

62) Muller F. L., Song W., Liu Y., Chaudhuri A., Pieke-Dahl S., Strong R., Huang T., Epstein C. J., Roberts L. J., Csete M., Faulkner J. A. and Remmen H. V. (2006). Absence of $\mathrm{Cu}, \mathrm{Zn}$ superoxide dismutase leads to elevated oxidative stress and acceleration of age-dependent skeletal muscle atrophy. Free Radic. Biol. Med., 40: 19932004.

63) Sentman M. L., Granstrom M., Jakobson H., Reaume A., Basu S. and Marklund S. L. (2006). Phenotypes of mice lacking extracellular superoxide dismutase and copper and zinc containing superoxide dismutase. Journal of Biological Chemistry, 281(11): 6904-6909.

64) Pedraza-Chaveri J., Maldonado P. D. and Medina-Campos O. (2000). Garlic ameliorates gentamicin nephrotoxicity: relation antioxidant enzymes. Free Radical Bio. Med., 29: 602-611.

65) Yazar E., Elmas M., Altunok V., Sivrikaya A., Oztekin E. and Birdane Y. O. (2003). Effects of aminoglycosides antibiotics on renal antioxidants, malondialdehyde levels, and some serum biochemical parameters. The Canadian Journal of Veterinary Research, 67: 239-240. 